\title{
ASUPAN GIZI SEIMBANG TINGKATKAN IMUNITAS TUBUH SAAT PANDEMI COVID-19
}

\author{
Alexander Halim Santoso ${ }^{1}$, Sung Chian ${ }^{2}$ \\ ${ }^{1}$ Bagian Ilmu Gizi, Fakultas Kedokteran, Universitas Tarumanagara Jakarta \\ Surel: alexanders@fk.untar.ac.id \\ ${ }^{2}$ Mahasiswa Fakultas Kedokteran, Universitas Tarumanagara Jakarta \\ Surel: Sung.405180113@stu.untar.ac.id
}

\begin{abstract}
Coronavirus Disease 2019 (COVID-19) is an infectious disease caused by the Coronavirus of the genus Severe Acute Respiratory Syndrome Human Corona virus (SARS-HCoV). Transmission of this disease occurs through close contact, especially through respiratory droplets when the patient coughs or sneezes. Most people with this disease recover spontaneously, but some experience a fatal worsening including organ failure, septic shock, pulmonary edema, severe pneumonia and acute respiratory distress syndrome (ARDS). Breaking the chain of transmission is the key to stopping the spread of this disease. The World Health Organization, WHO, said that there are three things that can be done to prevent the spread of this disease, namely by keeping a distance, not being in a closed room, and limiting mobilization (not gathering). Increasing body immunity by implementing a clean and healthy lifestyle (PHBS) such as consuming balanced nutrition, physical activity for at least 30 minutes a day, adequate rest, utilizing traditional health are part of disease prevention measures. Changes in the learning system during the pandemic made students easily exposed to various incorrect information. Efforts are needed to explain to students to increase students' awareness of the Covid-19 disease and its prevention steps
\end{abstract}

Keywords: Covid-19, immunity, prevention, balanced diet

\begin{abstract}
ABSTRAK
Coronavirus Disease 2019 (COVID-19) merupakan penyakit menular yang disebabkan oleh virus Coronavirus dari genus Severe Acute Respiratory Syndrome Human Coronarvirus (SARS-HCoV). Penularan penyakit ini terjadi kontak erat terutama melalui droplets saluran napas saat penderita batuk atau bersin. Sebagian besar penderita penyakit ini sembuh secara spontan, namun beberapa mengalami perburukan yang fatal mencakup gagal organ, syok septik, edema paru-paru, pneumonia berat dan sindrom gagal napas akut (acute respiratory distress syndrome/ARDS). Pemutusan rantai penularan merupakan kunci untuk menghentikan penyebaran penyakit ini. Organisasi Kesehatan Dunia, WHO, menyampaikan ada tiga hal yang dapat dilakukan untuk mencegah penyebaran penyakit ini yaitu dengan menjaga jarak, tidak berada dalam ruangan tertutup, dan membatasi mobilisasi (tidak berkumpul). Meningkatkan daya tahan tubuh dengan menerapkan pola hidup bersih sehat (PHBS) seperti mengonsumsi gizi seimbang, beraktivitas fisik minimal 30 menit sehari, istirahat yang cukup, memanfaatkan kesehatan tradisional merupakan bagian dari langkah-langkah pencegahan penyakit. Perubahan sistem pembelajaran selama Pandemi berlangsung membuat siswa mudah terpapar dengan berbagai informasi yang tidak benar. Diperlukan upaya penjelasan pada para siswa untuk meningkatkan kesadaran para siswa terhadap penyakit Covid-19 dan langkah-langkah pencegahannya.
\end{abstract}

Kata kunci: Covid-19, imunitas, pencegahan, gizi seimbang

\section{PENDAHULUAN}

Coronavirus Disease 2019 (COVID-19) merupakan penyakit menular yang disebabkan oleh virus Coronavirus dari genus Severe Acute Respiratory Syndrome Human Coronarvirus (SARS$H C o V$ ). Penyakit ini diawali dengan munculnya 27 kasus pneumonia yang tidak diketahui etiologinya di Wuhan, China pada akhir Desember 2019. Penderita penyakit ini memperlihatkan gejala gejala seperti batuk kering, dispnea, demam, dan gambaran infiltrate pada kedua paruparu. Sampai hari ini, sebagian besar penderita penyakit ini sembuh secara spontan, namun beberapa mengalami perburukan yang fatal mencakup gagal organ, syok septik, edema paruparu, pneumonia berat dan sindrom gagal napas akut (acute respiratory distress syndrome/ARDS). Pada manusia, penularan penyakit ini terjadi kontak erat terutama melalui 
droplets saluran napas saat penderita batuk atau bersin. Lebih dari limapuluh persen penderita berjenis kelamin laki-laki (54,3\%) dengan usia median 56 tahun. Penderita yang membutuhkan bantuan perawatan intensif didapatkan berusia lebih tua, dan memiliki sejumlah faktor komorbid seperti penyakit kardiovaskular, penyakit serebrovaskular, penyakit endokrin, penyakit saluran cerna, dan penyakit saluran napas.(Harapan et al., 2020; Sohrabi et al., 2020)

Pemutusan rantai penularan merupakan kunci untuk menghentikan penyebaran penyakit ini. Organisasi Kesehatan Dunia, WHO, menyampaikan ada tiga hal yang dapat dilakukan untuk mencegah penyebaran penyakit ini yaitu dengan menjaga jarak, tidak berada dalam ruangan tertutup, dan membatasi mobilisasi (tidak berkumpul). Kementerian Kesehatan Republik Indonesia dalam buku Pedoman Pencegahan dan Pengendalian Corovirus Disease (Covid-19) memberikan petunjuk pencegahan penularan penyakit dengan cara-cara (1) membersihkan tangan secara teratur dengan mencuci tangan menggunakan sabun dan air mengalir selama 40-60 detik atau menggunakan cairan antiseptik beralkohol minimal 20-30 detik, (2) menggunakan alat pelindung diri (APD) berupa masker yang menutupi hidung dan mulut jika harus bepergian keluar rumah atau bertemu dengan orang lain, (3) menjaga jarak minimal 1 meter dengan orang lain, (4) membatasi diri terhadap kontak dengan orang lain yang tidak diketahui status kesehatannya, (5) segera mandi dan berganti pakaian setelah kembali dari bepergian keluar rumah, dan (6) meningkatkan daya tahan tubuh dengan menerapkan pola hidup bersih sehat (PHBS) seperti mengonsumsi gizi seimbang, beraktivitas fisik minimal 30 menit sehari, istirahat yang cukup, memanfaatkan kesehatan tradisional.(Kementerian Kesehatan Republik Indonesia, 2020). Berdasarkan informasi yang didapatkan dari situs resmi pemerintah Republik Indonesia mengenai peta sebaran Covid-19 (www.covid19.go.id), didapatkan bahwa provinsi DKI Jakarta menyumbang 26,1\% terhadap total kasus Covid-19 Nasional. Berdasarkan data dari situs Covid19 provinsi DKI Jakart (Covid-19 (jakarta.go.id)), diketahui jumlah anak-remaja (usia 5-18 tahun) perempuan yang didiagnosis positif Covid-19 adalah 40,246 perempuan dan 38,967 anak laki-laki.

Laporan WHO menyatakan bahwa pada umumnya anak-anak dan remaja berisiko rendah terkena infeksi Covid-19. Akan tetapi, sejumlah anak dan remaja ditemukan mengalami kondisi yang buruk bahkan ada yang meninggal. WHO melaporkan bahwa anak-anak dan remaja di seluruh dunia mengalami dampak berat akibat pandem ini termasuk kesehatan dan kualitas hidup anakanak dan remaja. (COVID-19 and Children, 2021)

Selama pandemi, seluruh kegiatan belajar secara tatap muka langsung ditiadakan dan digantikan dengan cara daring dengan menggunakan berbagai aplikasi. Penggantian metode pembelajaran dilaporkan mempengaruhi gaya hidup daripada siswa, dimana siswa menjadi lebih banyak menjalani gaya hidup sedentari dan ditenggarai terjadinya peningkatan asupan makanan dalam seharinya(Unicef, 2020) Pemberitaan yang beragam melalui berbagai media juga turut mempengaruhi persepsi siswa mengenai asupan zat gizi yang benar untuk membantu daya tahan tubuh melawan infeksi Covid-19. Diperlukan upaya dalam memberikan informasi yang benar secara ilmiah kepada para siswa guna mencegah penurunan daya tahan tubuh akibat asupan zat gizi yang salah.(Xiang, Zhang, \& Kuwahara, 2020)

\section{METODE PELAKSANAAN PKM}

Pada hari pelaksanaan kegiatan, ruang pertemuan mulai dibuka pada jam 12.30 siang dengan menggunakan aplikasi Zoom. Para siswa dan narasumber kemudian mulai memasuki ruangan Zoom. Setelah jumlah peserta yang hadir sesuai, acara dibuka oleh perwakilan dari bagian Admisi Untar, Sdri Rachael. Acara kegiatan ini dihadiri juga oleh kepala Sekolah SMA Kristen Yusuf, Bapak Vendy, M.M, M.Pd. Para siswa kemudian diminta untuk mengisi daftar hadir dan juga kuesioner singkat dengan menggunakan goggle form (gform) yang dibagikan kepada para siswa 


\section{HASIL DAN PEMBAHASAN}

Pemaparan materi yang disampaikan oleh dr Alexander Halim Santoso, M.Gizi dari bagian Gizi, Fakultas Kedokteran, Universitas Tarumanagara. Asupan nutrisi yang adekuat dan seimbang merupakan salah satu kunci dalam pencegahan Covid-19. Tubuh membutuhkan semua zat gizi untuk pembentukan sistem imunitas yang baik di dalam tubuh. Panduan pemenuhian gizi yang adekuat dan seimbang dapat merujuk pada panduan oleh WHO yang disampaikan dalam "Isi Piringku".

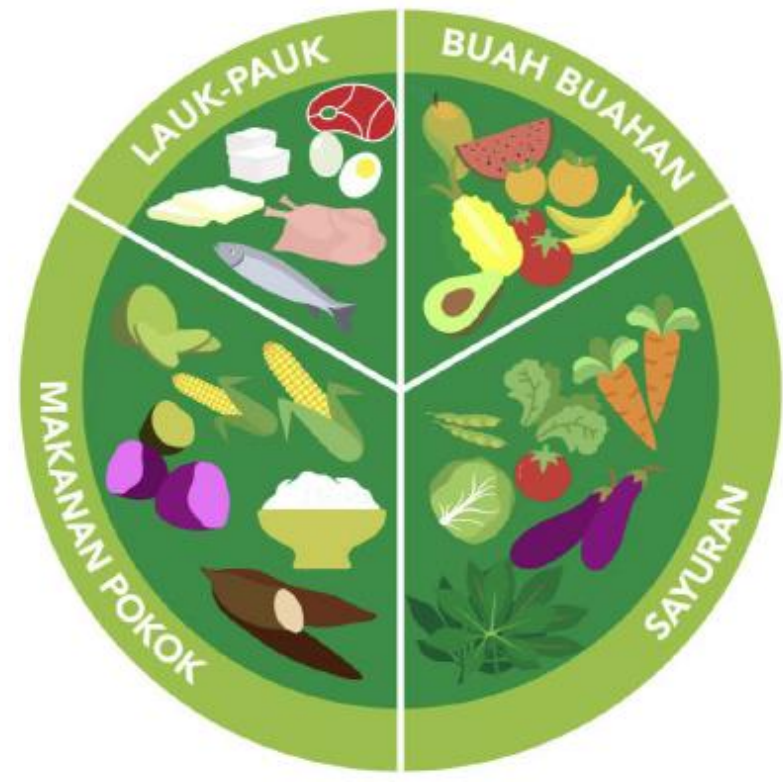

Gambar 1. Isi Piringku.(Kemenkes, 2014)

Berdasarkan panduan "Isi Piringku" disampaikan bahwa disamping asupan makanan pokok (nasi, jagung, singkong, ubi), asupan sayuran mendapatkan porsi yang sama besarnya. Asupan sayur sebanyak 3-4 porsi per hari dapat memberikan kecukupan serat yang dibutuhkan. Di samping asupan serat, sayuran juga mengandung vitamin dan mineral yang diperlukan oleh tubuh untuk membentuk sistem kekebalan tubuh yang optimal. Asupan buah-buahan disarankan sebanyak 2-3 porsi per hari. Disarankan mengonsumsi berbagai macam buah, karena buah-buah juga mengandung berbagai vitamin dan mineral dan berbagai fitonutrien, anti oksidan yang dapat membantu mencegah berbagai penyakit termasuk Covid-19.

Berdasarkan kajian-kajian penelitian dilaporkan beberapa vitamin dan mineral dilaporkan dapat membantu sistem kekebalan tubuh antara lain vitamin A, D, C, E, Zn. Vitamin A merupakan salah satu vitamin larut lemak yang berperan penting dalam menjaga fungsi penglihatan, menunjang pertumbuhan dan perkembangan, dan melindungi epitel dan integritas mukosa. Diketahui bahwa Vitamin A juga berperan penting dalam meningkatkan fungsi imun, dan juga meregulasi respons sistem imun baik imunitas selular dan humoral. Vitamin D yang juga merupakan vitamin larut lemak juga berperan dalam memodulasi respon imunitas alami dalam tubuh. Berbagai penelitian melaporkan adanya hubungan antara kadar rendah Vitamin D dengan meningkatnya risiko infeksi saluran pernapasan atas dan bawah. Vitamin E merupakan vitamin larut lemak yang memiliki efek anti-oksidan penting dan memiliki kemampuan memodulasi berbagai fungsi imunitas. Defisiensi vitamin E dilaporkan menganggu imunitas humoral dan seluler. Vitamin $\mathrm{C}$ memiliki peran anti-oksidan penting dan berperan sebagai ko-faktor dalam 


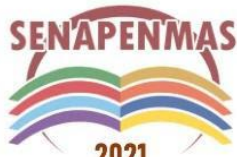

2021

pembentukkan hormon, kolagen, dan penguatan fungsi sistem imun. Zink merupakan traceelement penting yang berperan dalam pertumbuhan, perkembangan dan pemeliharaan fungsi imun. Defisiensi Zink dilaporkan berhubungan dengan meningkatnya risiko penyakit-penyakit infeksi. Selenium juga merupakan trace-element lain yang memiliki peranan yang luas mulai dari anti-oksidan hingga anti-inflamasi. Kadar Selenium yang rendah berhubungan dengan meningkatnya mortalitas, fungsi imun yang buruk, menurunnya fungsi kognitif.(Jayawardena, Sooriyaarachchi, Chourdakis, Jeewandara, \& Ranasinghe, 2020)

Seperenam dari bagian piringku dapat diisi dengan berbagai sumber lauk baik dari daging, ikan, telur.(Kemenkes, 2014) Disarankan untuk membatasi asupan gula, garam dan minyak dalam seharinya. Asupan gula, garam dan minyak yang berlebihan merupakan dasar terjadinya berbagai penyakit-penyakit sindrom metabolic, seperti diabetes mellitus, dislipidemia, hipertensi, dimana penyakit-penyakit ini merupakan faktor komorbid terhadap Covid-19. ASupan gula sebaiknya dibatasi $50 \mathrm{~g}$ per hari, asupan garam dibatasi 1 sendok teh per hari, dan asupan minyak dibatasi sebanyak 50 g per hari.(Kemenkes, 2014)

Kegiatan pengabdian ini dihadiri oleh 70 siswa kelas X SMA Kristen Yusuf dan 9 siswa dari kelas XI dan XII sebagai panitia. (Gambar 2) Dari 10 pertanyaan yang diberikan dalam kuesioner, didapatkan 26,9\% siswa mendapat skor baik (80-100), 52,6\% mendapat skor cukup (60-70) dan 20,5\% siswa mendapat skor kurang (0-50). (Gambar 3)
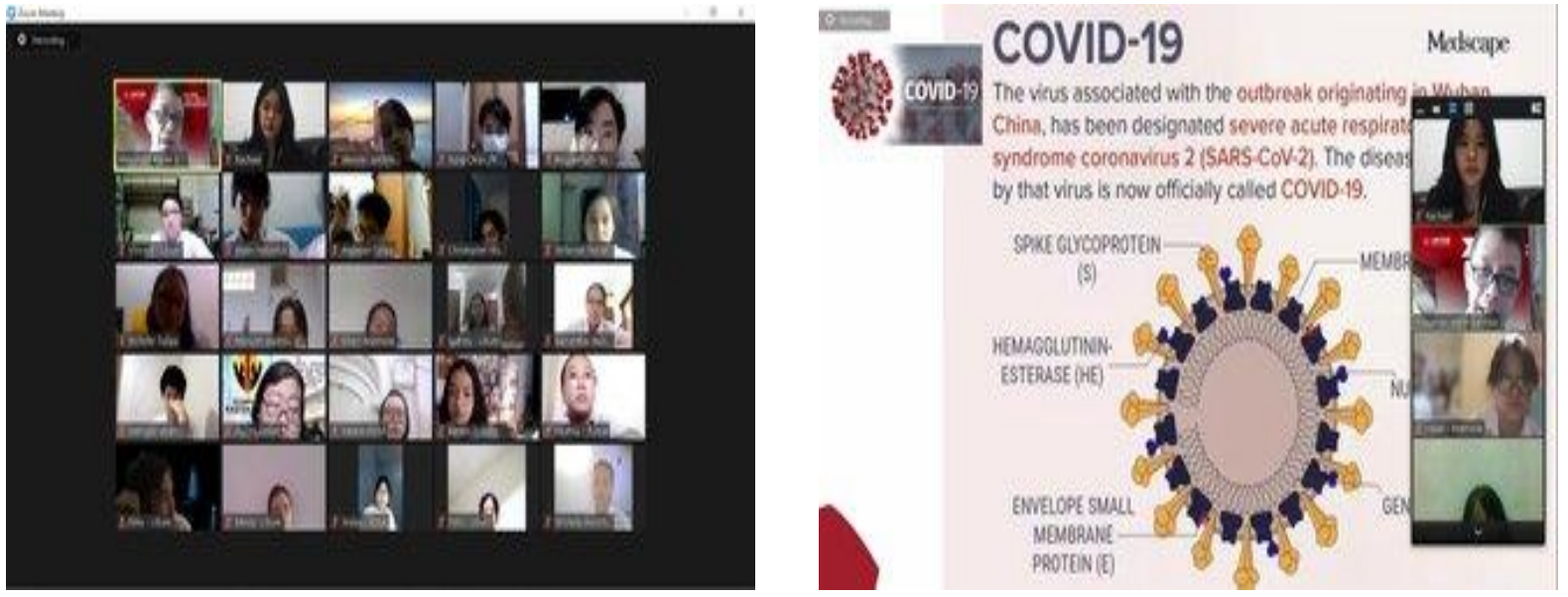

Gambar 2. Pelaksanaan Kegiatan

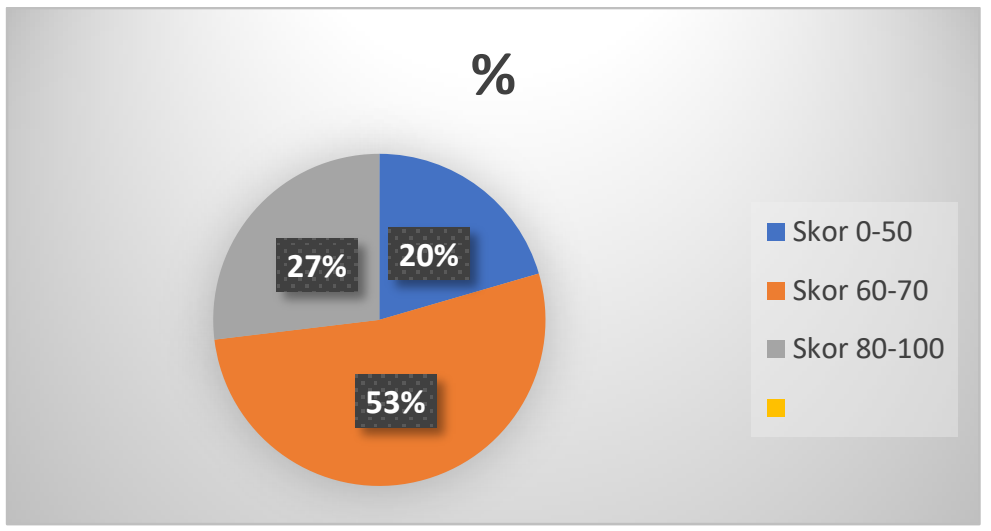

Gambar 3. Skor Hasil Pengisian Kuesioner 


\section{KESIMPULAN}

Kegiatan Pengabdian "Cegah Covid-19 Tingkatkan Imunitas Tubuh melalui Asupan Gizi Seimbang" kepada siswa Kelas X SMA Kristen Yusuf, Penjaringan, Jakarta Utara dalam bentuk daring terlaksana dengan baik dan diikuti oleh 79 siswa. Dari hasil pengisian kuesioner. didapatkan lebih dari limapuluh persen pengetahuan siswa terkait Covid-19 cukup baik. Covid19 merupakan suatu penyakit infeksi menular yang disebabkan oleh virus Sars-CoV-2 dan menyebabkan gangguan pada saluran napas hingga kematian. Pencegahan penularan merupakan kunci pemutusan rantai penularan penyakit. Asupan nutrisi yang adekuat dan seimbang dapat meningkatkan sistem imunitas pada tubuh sehingga dapat mencegah penularan. Kegiatan Pengabdian ini terlihat dapat meningkatkan wawasan para siswa mengenai peranan gizi di dalam meningkatkan daya tahan tubuh selama pandemic Covid-19. Walaupun demikian, masih diperlukan edukasi yang terus menerus guna meningkatkan kesadaran dari para siswa terhadap pencegahan Covid-19.

\section{Ucapan Terima Kasih}

Kami mengucapkan terima kasih kepada Yayasan Tarumanagara, Bapak Rektor Universitas Tarumanagara, Dekan Fakultas Kedokteran Universitas Tarumanagara, dan Ketua Lembaga Penelitian dan Pengabdian kepada Masyarakat Universitas Tarumanagara, Ibu Mei Ie, S.E, M.M selaku coordinator kegiatan Pengabdian PKM100 Plus, Wita dan Rachael yang membantu mengoordinir komunikasi dengan pihak sekolah atas dukungan yang diberikan mulai dari persiapan sampai penyelenggaraan kegiatan pengabdian ini. Kami juga mengucapkan terima kasih untuk dukungan dari Kepala Sekolah SMA Kristen Yusuf, Bpk. Vendy, MM, MPd, dan juga seluruh siswa SMA Kristen Yusuf yang sudah berpartisipasi dalam kegiatan ini.

\section{REFERENSI}

COVID-19 and Children. (2021). Retrieved from https://www.euro.who.int/en/healthtopics/Life-stages/child-and-adolescent-health/covid-19-and-children

Harapan, H., Itoh, N., Yufika, A., Winardi, W., Keam, S., Te, H., ... Mudatsir, M. (2020, May 1). Coronavirus disease 2019 (COVID-19): A literature review. Journal of Infection and Public Health, Vol. 13, pp. 667-673. https://doi.org/10.1016/j.jiph.2020.03.019

Jayawardena, R., Sooriyaarachchi, P., Chourdakis, M., Jeewandara, C., \& Ranasinghe, P. (2020). Enhancing immunity in viral infections, with special emphasis on COVID-19: A review. Diabetes \& Metabolic Syndrome, 14(4), 367. https://doi.org/10.1016/J.DSX.2020.04.015

Kemenkes. (2014). Pedoman Gizi Seimbang. In Kementerian Kesehatan Republik Indonesia.

Kementerian Kesehatan Republik Indonesia. (2020). Apa Yang Harus Dilakukan Masyarakat Untuk Cegah Penularan Covid-19. Kementerian Kesehatan Republik Indonesia.

Sohrabi, C., Alsafi, Z., O’Neill, N., Khan, M., Kerwan, A., Al-Jabir, A., ... Agha, R. (2020, April 1). World Health Organization declares global emergency: A review of the 2019 novel coronavirus (COVID-19). International Journal of Surgery, Vol. 76, pp. 71-76. https://doi.org/10.1016/j.ijsu.2020.02.034

Unicef. (2020). Child \& adolescent health and COVID-19. Retrieved July 24, 2021, from Unicef website: https://data.unicef.org/topic/child-health/child-health-and-covid-19/

Xiang, M., Zhang, Z., \& Kuwahara, K. (2020). Impact of COVID-19 pandemic on children and adolescents' lifestyle behavior larger than expected. Progress in Cardiovascular Diseases, 63(4), 531. https://doi.org/10.1016/J.PCAD.2020.04.013 
Seminar Nasional Hasil Penelitian dan Pengabdian Kepada Masyarakat 2021

Pengembangan Ekonomi Bangsa Melalui Inovasi Digital Hasil Penelitian dan

Pengabdian Kepada Masyarakat

Jakarta, 21 Oktober 2021

(halaman kosong) 